\title{
CONSTITUIÇÃO, TEMPO E NARRATIVA: DA CRISE DA ACELERAÇÃO DAS MUDANÇAS NORMATIVAS AO SEU ENFRENTAMENTO
}

Constitution, Time and Narrative: From the crisis of the acceleration of the legal changes to his confrontation

Ernane Salles da Costa Junior ${ }^{1}$

\begin{tabular}{|c|c|}
\hline RESUMO & ABSTRACT \\
\hline $\begin{array}{l}\text { O presente artigo procurou investigar a dimensão } \\
\text { temporal e narrativa das Constituições, tendo como } \\
\text { fundamento uma leitura da teoria narrativa e política } \\
\text { de Paul Ricoeur. Nesse caminho, aponta-se para a } \\
\text { necessidade de se pensar as mudanças normativas } \\
\text { dentro da história de uma comunidade política, } \\
\text { inserindo-as numa trama jurídico-narrativa que liga } \\
\text { passado, presente e futuro. Visa-se, com isso, } \\
\text { fundamentar uma crítica consistente e embasada em } \\
\text { relação à aceleração desenfreada dos ritmos das } \\
\text { transformações das normas jurídicas, tão comum nos } \\
\text { dias de hoje. }\end{array}$ & $\begin{array}{l}\text { this paper seeked to investigate the temporal and } \\
\text { narrative dimension of the Constitutions, based upon a } \\
\text { reading of the narrative and political theory of Paul } \\
\text { Ricoeur. In this way, it points to the need of thinking } \\
\text { the legal changes within the history of a political } \\
\text { community, inserting them in a narrative-juridical } \\
\text { intrigue that links past, present and future. The aim is, } \\
\text { thus, establish a consistent and solid critique about } \\
\text { runaway acceleration of the rhythms of the changes of } \\
\text { the legal standards, so common nowadays. }\end{array}$ \\
\hline $\begin{array}{l}\text { Palavras-chave: Constituição; Narrativa; Tempo e } \\
\text { Direito }\end{array}$ & Key-words: Constitution; Narrative; Time and Law \\
\hline
\end{tabular}

\section{Introdução}

O presente artigo procura compreender adequadamente as imbricações existentes entre tempo e Constituição.

Um dos principais aspectos dessa relação que podemos notar é que a Constituição, apesar de sua pretensão de permanecer durável na história, está imersa na temporalidade, sofre seus efeitos, submetendo-se à possibilidade contínua de alteração.

Por isso mesmo, presume-se que ela não se encontra presa a um momento fundador único situado no passado, mas experimenta, no transcurso do tempo, a necessidade de transformação, de reajustamento à estrutura cambiante da comunidade histórica: a Constituição dura, mas se modifica; permanece, mas flui (VERDÚ, 1984, p.187-188).

\footnotetext{
${ }^{1}$ Mestre em Teoria do Direito pela Pontifícia Universidade Católica de Minas Gerais com a distinção "magna cum laude". Foi bolsista do CNPq no mestrado pela mesma instituição. Atualmente é professor de "Filosofia do Direito", de "Ética, Política e Sociedade" e "Teoria da Constituição"Constituição, tempo e narrativa: da crise da aceleração das mudanças normativas ao seu enfrentamento na Faculdade Pitágoras. ernane.salles@hotmail.com
} 
Nasce aqui uma questão importante que nos serviu de fio condutor em todo o percurso de nossa análise: como, de fato, a Constituição é capaz de se modificar, de se alterar, sem, contudo, perder o fio do tempo?

É precisamente a partir dessa indagação e à luz das reflexões do filósofo francês Paul Ricoeur que procuraremos demonstrar que o desenvolvimento de uma Constituição ao longo da história precisa articular narrativamente passado e futuro, experiência e expectativa, memória e projeto, de modo a criar um padrão consistente que torna possível pensar e regular a sua própria mudança

\section{O Tempo da Constituição fora dos eixos}

Tem sido enfatizado reiteradamente o fato das Constituições serem consideradas textos normativos "abertos ao futuro" (LUHMANN, 1996; CATTONI DE OLIVEIRA, 2009) o que significaria dizer que tais normas são passíveis de modificação no tempo de modo a adaptar-se aos contextos históricos vindouros. Desse modo, a Constituição não poderia ser pensada como o resultado de uma construção única, acontecida de uma única vez, mas como um projeto que transforma o ato fundador político num procedimento que tem continuidade por meio de sucessivas gerações, seja a partir da interpretação do texto constitucional seja a partir da sua reforma (CATTONI DE OLIVEIRA, 2009).

Esse aspecto coloca em evidência a própria possibilidade de uma Constituição contemplar o dinamismo do seu tempo histórico como o resultado de um desenvolvimento evolutivo do direito e da sociedade. Não há dúvidas, portanto, acerca da imprescindibilidade da abertura do texto constitucional às mudanças, tendo em vista especialmente que a Constituição é produto de um processo sempre passível de maior elaboração e aperfeiçoamento no futuro.

No entanto, a situação da mutabilidade constitucional no tempo é mais complexa do que parece. Dizer que as Constituições encontram-se sempre suscetíveis de sofrer modificações ou que elas são "abertas ao futuro" exige ainda maiores precauções no sentido de que precisamos estar atentos ao modo e ao grau dessa abertura (CATTONI DE OLIVEIRA, 2009, p. 388). 
Quanto mais a produção normativa caminha nessa linha, aumentando o número de mudanças na Constituição, mais as normas constitucionais vão se expandindo de maneira confusa e desordenada. O resultado imediato dessa expansão caótica se expressa na dificuldade crescente de nossas sociedades para inscreverem-se numa duração significante, como se o presente, saturado pelo instantâneo, fosse, desde então, incapaz tanto de memória como de projeto (OST, 2005b, p.27). Mergulhadas nessa brecha do presente (OST, 2005b, p.28), nossas ordens constitucionais parecem órfãs de sua própria história e condenadas a submeter-se a mudanças produzidas segundo intervalos cada vez mais curtos de tempo. É desse modo que a crença obstinada na aceleração do tempo e dos ritmos das transformações jurídicas provoca uma espécie de encolhimento do nosso espaço de experiência e de um distanciamento de nosso horizonte de esperança: "o presente assim cindido em si mesmo reflete-se em crise, o que talvez seja [...] uma das significações maiores de nosso presente" (RICOEUR, 1997, p. 367).

A crise que marca profundamente nossos tempos é apontada por Ricoeur (1994a, p.8990) como um reflexo do empobrecimento do presente, entendido em termos de capacidade de iniciativa e de intervenção no rumo das coisas, o que implicaria a perda de todo o sentido da história, de toda orientação no tempo histórico. Dentro desse contexto, os homens e suas comunidades políticas, incapazes de articular narrativas e promessas, vivenciariam uma espécie de "encurtamento do tempo" (KOSELLECK, 2003, p.62) sustentado, agora, no instantaneísmo e na supervalorização do presente: como se o passado, definitivamente, terminado, nada mais tivesse a dizer, e que o futuro, decididamente demasiado incerto, não exigisse ser construído a partir de hoje (OST, 2005b, p. 28). Tal fenômeno, aliás, levou autores como Harvey a afirmar que "o tempo da pós-modernidade é o agora" (HARVEY, 2003, p.8) e juristas, como Kirste, a salientar que a produção do direito, nos tempos atuais, é marcada por um "presentismo, no qual a memória quase que perdeu sua função" (KIRSTE, 2008, p. 138). Nesse cenário de aceleração do tempo do direito e da política, "o agora converteu-se em absoluto, o que exaspera a necessidade de consumi-lo exaustivamente" (OLIVA-AUGUSTO, 1994, p.98).

Em consequência, a vivência do momento presente, para grande parte dos homens contemporâneos, antes de possibilitar a percepção de si como seres completos, indivíduos na 
112

extensão do termo, fá-los sentirem-se como seres desconectados, sem raízes e sem perspectivas (OLIVA-AUGUSTO, 1994, p.97). "Volátil e efêmera, hoje nossa experiência desconhece qualquer sentido de continuidade e se esgota em um presente sentido como instante fugaz" (CHAUÍ, 2006, p. 33). É desse modo que o instante do presente, destacado da dialética entre o espaço de experiência e o horizonte de expectativa, ensejaria, por um lado, a redução da tradição a um depósito sedimentado e petrificado, que alguns exaltam e que outros se esforçam por cobrir e enterrar; e, por outro, o desprezo dos projetos políticos de médio e curto prazo, tornando-nos reféns das utopias de sonho que arruínam toda vontade razoável e tenaz de reformas. (RICOEUR, 1994a, p.89). Somos, assim, conduzidos de maneira quase mecânica a valorizar o instante mutável do agora e, por isso, também a crescente velocidade em que brotam as informações de todo tipo ${ }^{2}$, as inovações normativas e os programas políticos de curto prazo. Contudo, o diagnóstico é de que nem mesmo a aceleração dessas mudanças nos torna mais aptos ou mais dispostos a transformar, de fato, o rumo da nossa realidade jurídico-política. Enfim, nossas normas e projetos políticos estão mais que nunca abertos ao futuro, mas esta representação do amanhã surge, ao mesmo tempo, singularmente oca de sentido, incapaz, certamente, de mobilizar as energias e suscitar o apetite para construção de tempos mais promissores (OST, 2005b, p.33).

Todo esse processo encontra alguma explicação na forma pela qual a temporalidade vem sendo vivida hodiernamente, no significado assumido, hoje, pelo tempo, mesmo se o compararmos ao tempo acelerado do progresso típico da modernidade (RICOEUR, 1994a, 1997, p.359-405; MARRAMAO, 1995, p.168-171; 2008; KOSELECK 2003; OLIVIAAUGUSTO, 1994). Surge, com a modernidade, a crença de que a época presente abre sobre o futuro a perspectiva de uma novidade nunca antes vista na qual os homens são cada vez mais capazes de fazer sua história e, com isso, acelerar as mudanças para o melhor (RICOEUR, 1997, p. 363). O constitucionalismo aparece, nesse momento, como uma possibilidade concreta dos próprios cidadãos projetarem seu amanhã na confiança de uma humanidade livre e igual apta a escrever, por si mesma, uma narrativa que propiciaria, em um só tempo, a felicidade individual e o bem comum. A norma, então, representa o início, a capacidade de começar algo no mundo que inspira as ações que haverão de se seguir e permanecer atuante

\footnotetext{
$2{ }^{2}$ Sobre a aceleração das informações e seus impactos, ver Moretzsohn (2000).
} 
durante todo o tempo que se prolonga após sua fundação (ARENDT, 1990, p. 170). Motivados pela promessa constitucional, os cidadãos se viram impulsionados a transformar a realidade e a investir no futuro como ideia inspiradora dessa crença nos valores universais e no progresso ${ }^{3}$. Mas o que ocorre nos tempos atuais é que a ideia de progresso que ainda vinculava ao passado um futuro melhor, tornando-o ainda mais próximo pela aceleração da história $^{4}$, tende a ceder o lugar para a utopia no seu sentido mais patológico, tão logo as esperanças da humanidade perdem toda ancoragem na experiência adquirida e são projetadas num futuro propriamente sem precedentes (RICOEUR, 1997, p.371). Já quase não acreditamos na marcha rumo ao progresso, mesmo que possamos falar, com razão, de aceleração no curso das mudanças: no fundo, a ideia de que os espaços de tempo que nos separam de tempos melhores estejam se encolhendo é, diante dos demasiados desastres recentes ou desordens em curso, algo em que não mais depositamos tanta confiança (RICOEUR, 1997, p. 367):

Com a passagem da era do progresso à era da modernização, a futurização perde sua polaridade axiológica, deixando livre o caminho para a pura e simples aceleração: o desejo e a tensão do futuro se revertem em frustração e 'anomia'. O Moderno, de excitante aventura das margens e dos limites, transforma-se numa progressão geométrica eternamente ameaçada pelo abismo e pela voragem do presente. O Futuro não é mais intencionado e projetado como finalidade, mas como etapa a ser queimada: existe apenas para ser consumido o mais rapidamente possível e deixado para trás, depositado na margem perigosamente mínima deixada à experiência. A época da modernização é a época do definitivo 'contrair-se' do hiato entre passado e futuro, do futuro que transcorre com imperceptível rapidez no passado: é a época do vergangene Zukunft, do futuro passado (MARRAMAO, 1995, p.118-119).

\footnotetext{
${ }^{3} \mathrm{O}$ curioso é que, apesar da ideia motivadora do progresso implicar a aceleração da mudança da história, os modernos conceberam o texto constitucional como um documento que deveria se prolongar por gerações de forma a vincular o futuro. De certo modo, isso ocorreu até mesmo porque a Constituição representou a materialização dos valores universais e fundamentais sob o qual se apoiavam o próprio impulso revolucionário. Bonavides, inclusive, narra um episódio que evidencia bem essa questão: "A pretensão à imutabilidade foi o sonho de alguns iluministas do século XVIII. Cegos de confiança no poder da razão, queriam eles a lei como produto lógico e absoluto, válido para todas as sociedades, atualizado para todas as gerações. Dessa fanática esperança comungou um membro da Convenção, conforme nos lembra notável publicista francês, pedindo durante os debates do Ano III a pena de morte para todo aquele que ousasse propor a reforma da Constituição" (BONAVIDES, 1998, p.173).

44 "Se o progresso pode ser acelerado, é porque podemos apressar o seu curso e lutar contra o que atrasa, reação e sobrevivências ruins" (RICOEUR, 1997, p.365).
} 
114

Como marca de nossos tempos, o "futuro passado", que Marramao enfatiza, é o próprio tempo-a-perder, tempo de mera subtração, que faz com que o amanhã perca seu significado prospectivo: "ele é antes uma fronteira fugaz que se retira e que deixamos para trás, como as dunas de areia" (MARRAMAO, 1995, p. 119). É assim que o fenômeno da queda do futuro, como potência simbólica, implicaria o déficit crônico de legitimação dos Estados contemporâneos (MARRAMAO, 1995, p. 170). Na medida em que as estruturas institucionais e normativas não estão mais aptas a traçar planos de médio e longo prazo e de projetarem suas próprias finalidades e promessas ao longo do tempo de uma comunidade histórica, a produção de sentido político, construída sob as bases de um "viver junto", fica fortemente comprometida dando lugar ao "sentimento do aleatório" (RICOEUR, 1994a, p.90). É nesse sentido que assistimos, a todo o momento, uma privatização dos projetos, um culto a um consumismo míope, um desengajamento em relação a toda responsabilidade cívica (RICOEUR, 1994a, p.89). Com a dificuldade de manter vivo o simbolismo social (MARRAMAO, 1995, p.170), nossas Constituições, entendidas como uma série de compromissos normativos que nasce e se estende na história política de um povo na direção de fomentar o seu futuro aprendizado, são reduzidas a utopias irrealizáveis, incapazes de guiar nossas ações para realização efetiva das promessas que fizemos a nós mesmos no passado. Resta-nos, sem a devida confiança na Constituição para administrar um futuro libertador, ajustar constantemente nossos compromissos constitucionais de forma a adequá-los às pressões dos fatos presentes, das urgências e dos fatores reais de poder ${ }^{5}$.

A aceleração desenfreada das estruturas institucionais e normativas esvazia-se, assim, de sentido, por não ser mais possível o recurso simbolicamente eficaz aos ideais do progresso e da revolução (MARRAMAO, 1995, p. 170), dentre os quais incluímos a própria ideia inspiradora de uma Constituição imbricada nas grandes reviravoltas políticas do final do século XVIII. Como efeito, hodiernamente nossas Constituições são, com mais frequência, concebidas como instrumento de ação do que propriamente como estrutura para a ação

\footnotetext{
55 "Igualmente perigosa para força normativa da Constituição afigura-se a tendência para frequente revisão constitucional sob a alegação de suposta e inarredável necessidade política. Cada reforma constitucional expressa a ideia de que, efetiva ou aparentemente, atribui-se maior valor às exigências de índole fática do que à ordem normativa vigente. Os precedentes aqui são, por isso, particularmente preocupantes. A frequência das reformas constitucionais abala a confiança na sua inquebrantabilidade, debilitando a sua força normativa. A estabilidade constitui condição fundamental da eficácia da Constituição" (HESSE, 1991, p.22).
} 
(SILVA, 2005, p.239). A Constituição como instrumento de ação significa a possibilidade de o sistema político dispor de seu texto, por meio de reforma, para a implementação da política; já como estrutura para a ação, o significado é o de que a Constituição é tomada como orientação e parâmetro de atuação do sistema político, este que vai reformar não mais o texto constitucional, mas a própria realidade inconstitucional (SILVA, 2005, p.239-240).

O tempo da Constituição aqui, mais uma vez, parece estar fora dos seus eixos. Num primeiro instante, ele apresenta-se demasiadamente veloz quando o assunto é a reforma das leis, dos códigos e, até mesmo, dos nossos compromissos normativos mais fundamentais: passa-se rapidamente de leis existentes para leis novas, sem, contudo, considerar o ideal de durabilidade sob o qual nossas ordens constitucionais se sustentam e sem o qual, insistimos, não há, de fato, força normativa. Sob outro ângulo, diríamos que esse tempo é demasiadamente lento no que concerne às transformações sociais efetivas, na medida em que permanece incapaz de operar, efetivamente, a diminuição da dissimetria entre "eu" e "outro" no âmbito do exercício da atividade política e jurídica. Vemos, nesse contexto, a formação de um pensamento um tanto quanto duvidoso, no qual vem embutida a necessidade de reforma constitucional como válvula de escape para os problemas sociais, culturais, econômicos e políticos a serem enfrentados numa dada realidade. Contudo, o que não é possível identificar, juntamente com essa valorização das mudanças normativas, é mesmo o desenvolvimento de uma tomada de consciência crítica acerca da fenda temporal que se abre entre tempo do direito e tempo da sociedade.

É desse modo que enfatizamos que a passagem de uma norma a outra deixa-se aproximar da dialética de inovação e de sedimentação intrínseca à estrutura narrativa do direito no sentido de se conceber a Constituição como um importante roteiro no qual a comunidade política, como um todo, se vê responsável pela escrita e continuação de sua história jurídica e da sua autoimagem no plano institucional. "Fora dessa dialética, o conceito de transformação, inteiramente pensado em termos de corte, ameaça reconduzir à concepção 


\section{6}

eleática do tempo ${ }^{6}$, que, em Zenão, leva a compor o tempo de minima insecáveis" (RICOEUR, 1997, p.376).

Como analogia à figura do tempo elaborada por Zenão e recordada por Ricoeur, as transformações constitucionais parecem mais um conjunto de manifestações jurídicas individualizadas, pontuais e separadas umas das outras quando não pensadas à luz da dimensão narrativa do direito. Da dinâmica de uma Constituição no tempo, tomaríamos, então, apenas um conhecimento sincrônico, por cortes sucessivos, em que a única exigência de incorporação de normas novas reside na obrigação de passar pelo crive formal do próprio ordenamento jurídico. Mas se apropriarmos aqui de uma metáfora da produção cinematográfica, talvez possamos aproximar nosso estudo um pouco mais de uma dimensão narrativa do direito.

Numa perspectiva de aceleração constante das reformas constitucionais, uma dada mudança no sistema jurídico sucede a uma outra como imagens de um filme que desfilam de maneira sincopada, sem que se explique a sequência geral da história (OST, 2005a, p. 46). É preciso, então, que a "montagem" opere-se segundo um "cenário" que torne inteligível e aceitável o desenvolvimento das imagens (OST, 2005b, p. 230). Somente uma produção jurídica, compreendida em termos narrativos, por integrar a dimensão temporal do direito, tem condições de restituir o roteiro da história constitucional de uma comunidade política ${ }^{7}$. Assim, retoma-se o valor dos princípios e dos direitos fundamentais enraizados simultaneamente numa memória e portadores de um projeto de futuro, como forma de se dar prosseguimento à narrativa jurídica que queremos, coletivamente, e continuar contando.

Portanto, mais que uma sucessão irregular de atos jurídicos instantâneos, a transformação do texto constitucional é um processo de "ajuste" ao longo do tempo, que toma a história da própria comunidade política como pano de fundo para construção de um tempo jurídico próprio, suscetível de operar uma regulação em profundidade das mudanças duradouramente assimiláveis pelo corpo social (OST, 2005b, p. 231). É, precisamente, a partir

\footnotetext{
${ }^{6}{ }^{6}$ Tanto Zenão quanto os outros eleatas, como Parmênides, partiam da idéia de uma unidade estática do tempo. Trata-se de uma oposição direta ao mobilismo preconizado por Heráclito, para quem "tudo passa e nada permanece". Para provar que o movimento é impossível, Zenão elabora alguns paradoxos, que nos levam a pensar o tempo como infinitamente divisível, como se fosse composto por uma sucessão infinita de "agoras" e instantes individuais e descontínuos.

${ }^{7}$ Sobre esse aspecto narrativo do desenvolvimento de uma Constituição no tempo, ver Costa Junior (2009).
} 
desse tempo da Constituição, que se opera entre mudança e permanência, que nos encontramos autorizados a retomar o valor da promessa política e seu papel central na obra de Ricoeur. A promessa é um colocar-se intencionalmente na obrigação de fazer o que se diz, impondo a si mesmo uma obrigação estabelecida no presente que compromete o futuro (RICOEUR, 1997, p. 396; 2006, p. 123-138; 2007; 1991a). Prometer, de fato, a partir de uma Carta Constucional, é também prometer manter a própria promessa. Assim, manter a palavra é fazer com que a iniciativa tenha uma sequência, com que a iniciativa inaugure realmente um novo curso de coisas, em suma, com que o presente não seja apenas uma incidência, mas sim o começo de uma continuação (RICOEUR, 1997, p. 396).

Se for verdade, então, que a Constituição traz no seu texto acordos sobre os princípios fundadores do corpo político, como promessas que engajam um futuro comum, e não como ordens conjunturais, há a oportunidade de preservá-la da contingência sócio-política e das interpretações desinstituintes; não para colocar o texto constitucional "fora do tempo", mas para defender-lhes os valores constitutivos do tempo concreto da vida social efetiva (OST, 2005b, p. 231). E isso significa que a Constituição precisa ser defendida do tempo acelerado que marca nossos dias, na medida em que é compreendida como um modo de fidelidade no tempo a uma causa política superior sob a qual se apóiam nossas esperanças políticas de futuro. É justamente aí que acreditamos encontrar um dos mais preciosos legados deixados pelo pensamento de Ricoeur para refletir o problema do direito na contemporaneidade: a ideia propulsora de que não basta identificar nossos tempos como tempos de crise, é preciso enfrentá-la a partir de nossos próprios compromissos.

\section{Da crise ao seu enfrentamento: por uma nova reflexão da dialética entre tempo e Constituição}

\subsection{Um passado revisitado}

A primeira e mais clara implicação da aceleração dos ritmos das reformas normativas consiste na mudança, na forma de se conceber a dimensão temporal do direito, mais 


\section{8}

precisamente no seu deslocamento do passado para o futuro. Na medida em que vivemos num tempo em que a velocidade das modificações legais aponta para uma constante e urgente necessidade de mudança, observamos, progressivamente, uma queda substancial da nossa capacidade de recorrer à experiência contida no passado. Tudo se passa como se, ilusoriamente, estivéssemos aptos, a cada mudança de lei, a nos lançar do presente direto para o futuro, sem que precisássemos nos preocupar tanto com as orientações normativas do passado quanto ao modo apropriado de se articular as instituições vigentes para tornar viável a transformação gradual da realidade política.

Esse desprezo pelo trabalho do tempo, como traço marcante dos dias atuais, conduz a uma impossibilidade de se reorganizar as experiências jurídicas passadas na direção de se construir uma narrativa constitucional capaz de dar sentido e rumo às transformações normativas mais importantes do nosso corpo político. Carente desse elo com o passado, a construção do direito estaria, assim, submetida a uma amnésia continuada da sua própria experiência histórica (SARAPU, 2007) numa situação na qual cada modificação legal poderia se impor por si mesma: esquece-se tudo e recomeça de novo. O problema dessa situação é que a reforma constitucional corre o risco de se autonomizar: sem referência a uma tradição jurídica de construção da cidadania ou a um momento inaugural capaz de mobilizar nossas esperanças de futuro, estamos fadados a não mais captar a "inovação" legislativa, de mesurar a sua mudança. É assim que o horizonte de expectativa, desconectado das promessas contidas no passado, se esvazia de todo o conteúdo, de todo objetivo digno de ser perseguido (RICOEUR, 1994a, p. 89).

Ora, "o passado ao qual o trabalhador jurídico (Müller) se reporta tem um começo temporal claro e é dependente de seu momento presente" (KIRSTE, 2008, p. 132). Referimosnos, aqui, a uma Constituição e, mais precisamente, ao sentido normativo que ela expressa no processo constituinte de sua própria elaboração: a mútua promessa de um "querer viver junto" sob a base de princípios e direitos fundamentais reconhecidos reciprocamente pelos

\footnotetext{
$8{ }^{8}$ A ideia de um "viver junto" não significa fusão ou adesão a uma ideologia única, como se nós, homens, deixássemos nossas diferenças e concepções de "vida boa" de lado para formamos uma identidade uniforme e homogênea. "Viver junto" está mais ligado à concepção de "justa distância" na qual se aceita e respeita o outro na possibilidade de construção política de uma vida em comum. Muito próximo dessa perspectiva de Ricoeur, Roland Barthes em seu "Como viver junto" (2003) empreende esforços para refletir acerca da distância que devemos nos manter de nossos semelhantes para construir com os outros uma sociabilidade sem alienação.
} 
cidadãos e duráveis no tempo. Dessa maneira, espera-se que toda discussão em torno de modificações das normas constitucionais perpasse, retrospectivamente, pelo significado da fundação do corpo político que toda Constituição procura preservar ${ }^{9}$. Rememorar o ato inaugural da comunidade política é, pois, abrir-se para a necessidade de manter viva a importância desse projeto de um "reconhecimento mútuo" que representa o ato de fundação constitucional. O que acontece, porém, é que a trivialização de mudanças na Constituição, como temos insistido, ao carecer dessa retomada a um passado comprometido com o futuro, tende a desconectar-se da origem levando ao "esquecimento do reconhecimento" (HONNETH, 2008, p.69). Numa atitude irrefletida, as normas jurídicas novas vão tomando o lugar das antigas numa velocidade tão grande que a comunidade política torna-se incapaz de revisitar, a cada reforma, o sentido dos percursos das histórias de conquistas de direitos sob a qual a Constituição se sustenta ${ }^{10}$. É assim que, sem grandes dificuldades, nossos direitos e compromissos mais fundamentais, aqueles pertencentes ao núcleo imodificável de toda Constituição, passam a ser também mitigados. A partir desse desprezo do valor da durabilidade, assistimos a uma queda de credibilidade das instituições jurídicas e políticas e a perda crescente do papel simbólico das Cartas Constitucionais nas sociedades contemporâneas. Os cidadãos, então, destituídos de uma orientação no tempo histórico, se esquecem que as instituições só existem em razão de um querer viver junto o que acaba por tornar ainda mais frágeis as possibilidades concretas de fortalecer os laços sociais imprescindíveis para a construção de uma vida em comum (RICOEUR, 1994a, p.90).

No entanto, não é a modificação normativa em si, "mas sim a sua rotinização e habitualização que podem levar a "esquecer", no final, todo reconhecimento original" (HONNETH, 2008, p.77). Por isso, contra esse processo de mudança constitucional de rupturas e descontinuidades aceleradas, restituímos a narratividade como virtude da construção normativa até o ponto do "ser-afetado pelo passado" que Ricoeur tanto enfatiza em suas obras. Uma vez que entendemos as Constituições como coisas ditas no passado e

\footnotetext{
${ }^{9}$ É nesse sentido que Ost (2005a, p. 29) afirma que no preâmbulo de toda Constituição há um relato ora muito desenvolvido, ora reduzido a algumas linhas, que evoca o que deverá figurar doravante como o momento forte da comunidade ou o que a liga a um passado imemorial fundador.

110 “A positivação de tais direitos [fundamentais] no texto constitucional é fruto da visibilidade que as questões que o originaram conquistaram nas lutas sociais e torna visível a pretensão por ele envolvida em um novo patamar" (GALUPPO, 2009, 268).
} 
transmitidas até nós por uma cadeia de interpretações e de reinterpretações, é preciso que continuemos a contar a história constitucional que nos foi legada sem, propriamente, perder o fio das nossas experiências jurídicas no tempo: "o passado nos interroga na medida em que o interrogamos. Ele nos responde na medida em que lhe respondemos" (RICOEUR, 1997, p.381).

Desse modo, a noção de "ser-afetado pelo passado" na construção da atividade legislativa "opõe-se, ao mesmo tempo, à do passado tido como meramente findo, abolido, absolvido, e a de contemporaneidade integral que foi o ideal hermenêutico da filosofia romântica" (RICOEUR, 1997, p. 378). Entre essas duas figuras, o passado é-nos revelado pela projeção de um horizonte histórico, ao mesmo tempo separado do horizonte do presente e retomado, reassumido por ele, o que, por sua vez, torna nossas experiências portadoras de sentido (RICOEUR, 2007, p. 378-379). Essa capacidade de se atribuir sentido ao passado possibilita que uma tradição jurídica, construída desde a fundação de uma Constituição, não seja concebida como um depósito inerte, mas como uma operação continuada no tempo de uma comunidade histórica que só se compreende no intercâmbio entre o passado interpretado e o presente interpretante. Nem totalmente prisioneiros da tradição e nem mesmo inteiramente libertos de suas heranças, nossas relações com o passado jurídico atentam, assim, ao fato de que, a um só tempo, "somos afetados pela história e [...] afetamos a nós mesmos pela história que fazemos" (RICOEUR, 1997, p.368). É nesse sentido que o passado constitucional não deixa de irradiar a sua luz no presente numa situação na qual fazemos sim nossa história constitucional escrevendo continuamente no tecido normativo de nossa Lei Fundamental, mas só a fazemos nas circunstâncias encontradas, dadas, transmitidas. Aliás, de maneira bem semelhante, Kirste desenvolve suas reflexões sobre a presença inafastável do passado na produção jurídica. Assim, ele afirma:

$\mathrm{Na}$ aplicação do direito, o indivíduo tem que pressupor a obrigação advinda do passado e se deixar motivar por ela. Na medida em que a legislação e a aplicação do direito estão vinculadas a outras normas e princípios jurídicos anteriores, a transformação de normas, no âmbito temporal do direito ("temporalização do direito"), exige o reconhecimento de tais normas e princípios" (KIRSTE, 2003, p. 121). 
Se para o fundador da Constituição, o tempo do direito está predominantemente ligado a um horizonte vindouro a ser moldado, para o continuador, o tempo do direito encontra-se fortemente enraizado num passado que deve ser lembrado, revivido, presentificado. Aliás, só somos capazes de construir os laços para a edificação de uma vida comum na medida em que assumimos o nosso passado e os seus símbolos e estamos, assim, aptos a interpretá-lo. A reforma constitucional é, dessa forma, uma tarefa hermenêutica que não se desliga de uma responsabilidade diante das heranças jurídicas. Ela, ao contrário, tem a obrigação de sempre torná-la ainda mais viva, porque reacende e dá continuidade às imagens dos desejos, dos sonhos e dos compromissos projetados por um povo. Por esse motivo, atribuímos ao poder reformador

\footnotetext{
o sentido de uma responsabilidade sem limites, portanto, necessariamente excessiva, incalculável, diante da memória; e, por conseguinte, a tarefa de lembrar a história, a origem e o sentido, isto é, os limites dos conceitos de justiça, de lei e de direito, dos valores, normas, prescrições que ali se impuseram e se sedimentaram, permanecendo, desde então, mais ou menos legíveis ou pressupostos (DERRIDA, 2007, p. 36-37).
}

Logo, "é criando lembranças de todos os começos e de todos os recomeços e de todas as tradições que se sedimentaram sobre sua base" (RICOEUR, 1991a, p. 306) que a construção do direito pode, enfim, superar a crise de legitimação que marca nossos dias. Tal crise - que, na visão de Ricoeur, se expressa na ideia da dominação se sobrepondo ao poder, entendido como querer viver e agir em conjunto de um povo - deve ser contestada pela reminiscência e o entrecruzamento no espaço público da aparição das tradições que dão lugar à tolerância e ao pluralismo (RICOEUR, 1991a, p. 306). Assim, não podemos nos esquecer que a tradição, na sua dimensão jurídico-política, nos lega a noção de constitucionalismo, representada pelas ideias de democracia e direitos fundamentais como partes constitutivas das promessas normativas que assumimos desde as grandes revoluções do final do século XVIII. Deixar ser afetado pelo passado na continuação da escrita constitucional é resgatar essas promessas de se construir uma sociedade melhor no futuro e não deixar que se apague o significado da "origem" de nossas instituições e dos percursos de reconhecimento dos direitos 
inscritos no texto de nossas Constituições ${ }^{11}$, pois, nossa tradição as considera como um documento político-jurídico criativo e fundador que conecta as origens de nossa sociedade ao seu próprio amanhã (GARCÍA-VILLEGAS, 2003, p. 1).

O passado constitucional, desse modo, não é um peso que vincula de antemão o futuro; como se não tivéssemos mais condições de vislumbrar o novo e de percorrer caminhos inéditos na concretização de direitos constitucionais no plano da realidade política. Nesse sentido, precisamos superar, à luz das reflexões de Ricoeur (1996, p. 4), um preconceito tenaz, a saber, a crença fortemente enraizada de que unicamente o futuro é indeterminado e aberto e o passado determinado e fechado. O sentido de uma Carta constitucional, fundada no passado, não está estabelecido de uma vez por todas. Não só o texto de uma Constituição, elaborado como explicitação de um querer viver junto de uma comunidade política, permanece aberto a interpretações, como também "se dá uma reviravolta nos nossos projetos, em função de nossas lembranças, por um notável efeito de acerto de contas" (RICOEUR, 1996, p. 5). Isso significa dizer que estamos sempre suscetíveis de narrar o projeto constitucional a partir de um apoio crítico no esforço por contar de outra maneira e do ponto de vista do outro os acontecimentos fundadores da nossa experiência política (RICOEUR, 1996, p. 5). Essa possibilidade de resgatar o nosso passado fundador de um modo diferente é aquilo que garante, ao mesmo tempo, nossa responsabilidade presente pelas histórias dos direitos e pelo "permanecer aberto" das democracias no sentido de um compromisso sempre vivo de passar pelas narrativas dos outros para compreendermos a nós mesmos enquanto sujeitos de uma identidade constitucional em permanente construção.

É assim que identificamos a necessidade de reinterpretação do passado como tarefa de fazer justiça, pela lembrança, a um outro com o qual sustentamos um sentimento de endividamento mútuo (RICOEUR, 2007, p. 101). Falamos, propriamente aqui, da responsabilidade de uma escrita jurídica do presente que perpasse pela re-leitura de nossa narrativa constitucional a partir dos olhos dos grupos socialmente excluídos que permaneceram, ao longo do tempo, na margem dessa história. Assim, mesmo nas

\footnotetext{
11 “É assim, também, que os direitos fundamentais se afirmam ao longo da história. Há lutas por reconhecimento que se travam na história, uma ordem pré-narrativa, uma pré-figuração, que antecede a fixação histórica dos direitos fundamentais. A Constituição é cheia de exemplos de como os direitos fundamentais são narrativamente configurados a partir de uma préfiguração historicamente dada" (GALUPPO, 2009, p.272).
} 
comunidades políticas mais pluralistas e multiculturais, nem todas as culturas, religiões, formas de vida podem ser representadas totalmente por uma identidade constitucional, existindo sempre pontos de vistas invisíveis que nosso ordenamento jurídico deixa nos seus limites ou mesmo exclui. Por isso, poderíamos dizer que a tradição jurídica revela-se portadora de promessas não cumpridas e bloqueadas, de expectativas e de sonhos que ainda continuam dependendo de uma concretização efetiva no presente. Ora, o tema de uma história constitucional viva, contínua e aberta parece surgir como "único capaz de amparar uma ação política vigorosa na memorização das potencialidades abafadas ou recalcadas do passado" (RICOEUR, 1997, p. 376).

É retomando nossa história de direitos prometidos, mas ainda não cumpridos - como o compromisso jurídico com a construção de uma sociedade política fraterna, pluralista e sem preconceitos expressos no preâmbulo da Constituição brasileira, ou ainda como os grandes ideais de igualdade e liberdade para todos como princípios propulsores da Revolução Francesa - que estamos aptos a reabrir o passado a partir das narrativas ainda não reconhecidas no plano jurídico para que assim possamos liberar sua carga de futuro. Quando insistimos, então, na importância de se manter sempre presente o sentido das "origens" que o processo constituinte de elaboração de uma Constituição se propõe a preservar ou mesmo a revivência retrospectiva dos percursos de reconhecimento de direitos ao longo da história de um povo e de toda a humanidade, inscritos no texto constitucional, pretendemos, na verdade, apontar para a necessidade continuada de se "reconduzir a esses momentos do passado em que o futuro ainda não estava decidido, em que o próprio passado era um espaço de experiência aberto para um horizonte de expectativa" (RICOEUR, 1997, p. 388). O interessante é então liberar essas expectativas e promessas que não foram satisfeitas e incorporá-las às nossas próprias expectativas de hoje, para lhes dar um conteúdo, de forma que possamos cobrá-las, aqui e agora, na própria dinâmica interna do processo de continuação da narrativa constitucional.

Assim, não é acelerando os ritmos das transformações normativas, correndo o risco inclusive da perda das memórias dos percursos de lutas por reconhecimento de direitos, que poderemos ver concretizada nossa esperança de uma realidade política mais justa e igualitária na qual as normas constitucionais são capazes de mobilizar na direção de atitudes 
verdadeiramente transformadoras. O empreendimento político-jurídico, a ser realizado, é o de se reabrir o próprio texto constitucional que temos - e, portanto, os significados do passado que ele carrega consigo -, levando-o a sério ${ }^{12}$ no sentido de deixar ser motivado pela sua proposta de mundo: a construção de um futuro responsável pelos direitos já inscritos no plano normativo cuja efetivação permanece ainda como promessas deixadas para trás. Só assim poderemos conceber a Constituição não mais como um "instrumento de ação", que necessita a todo o momento ser modificado, mas como "estrutura para a ação política", visto que procuraremos continuamente materializar os seus próprios preceitos.

É dessa maneira que retomamos a necessidade colocada por Ricoeur de reabilitação do político por meio da tarefa de relembrar, permanentemente, o sentido de nossas instituições e ir em socorro da sua fragilidade: "tudo fazer para que elas se possam transmitir e continuar, apesar de sua comoção" (ABEL, 1996, p. 120). Assim, sobretudo para nosso problema, essa orientação de Ricoeur nos conduz à importância de assumirmos nosso próprio legado institucional e normativo, reavivando sempre seus símbolos, suas promessas e, portanto, a sua capacidade de transformar o rumo das coisas. De modo a superar tempos de crise, nosso caminho parece apontar para uma necessidade de uma compreensão cada vez maior pelos próprios cidadãos do valor e do papel central de uma Constituição, das narrativas políticas e jurídicas que ela pretende imprimir no tempo de uma comunidade histórica. É preciso, então, em sentido contrário da corrida pela reforma no texto constitucional, fazer valer seus compromissos mais fundamentais, transformando o passado jurídico em projeto para que possamos dar-lhe, aqui e agora, uma forma de futuro e de esperança.

\subsection{Um futuro projetado}

A partir das orientações de Ricoeur, seguidas até aqui, procuramos superar uma visão reducionista do passado, que o compreende como um fardo da nossa história, algo fechado e

\footnotetext{
12 “A Constituição transforma-se em força ativa se essas tarefas forem efetivamente realizadas, se existir a disposição de orientar a própria conduta segundo a ordem estabelecida, se, a despeito de todos os questionamentos e reservas provenientes dos juízos de conveniência, se puder identificar a vontade de concretizar essa ordem. Concluindo, pode-se afirmar que a Constituição converter-se-á em força ativa se fizerem-se presentes, na consciência geral - particularmente, na consciência dos principais responsáveis pela ordem constitucional -, não só a vontade de poder (Wille zur Macht), mas também a vontade de Constituição (Wille zur Verfassung)" (HESSE, 1991, p. 19).
} 
determinante de nossas decisões no presente: como se presos à nossa tradição jurídica de maneira inexorável não estivéssemos aptos a vislumbrar o novo. Diferentemente dessa vontade tenaz de ultrapassá-lo, de vencê-lo a qualquer custo, é preciso ser afetado por ele para que nossas visões do futuro tenham força de reativar as potencialidades não realizadas e para que a história seja carregada por tradições ainda vivas (RICOEUR, 1997, p. 405). O passado, nesse contexto, é concebido como um espaço de experiência aberto no qual coabitam uma pluralidade de promessas, de projeções, de sonhos: sempre é possível narrá-lo de outro modo, extraindo dele uma capacidade de fomentar, hoje, nossas forças em direção a novos rumos de nossa realidade política. Certamente, os acontecimentos passados são inapagáveis: não podemos desfazer o que foi, nem fazer com que o que aconteceu não tenha acontecido (RICOEUR, 1996, p. 4). Mas ao invés, podemos tirar partido de seus ensinamentos, imprimirlhe outro sentido ou ainda assumir a responsabilidade por seus erros e pelos seus percursos de luta por direitos (OST, 2005b, p. 28). Eis a tarefa da rememoração do passado na continuação da narrativa constitucional.

Da mesma forma, podemos agora dizer que é preciso superar outra concepção que ainda persiste fortemente: a crença de que o futuro é em todos os aspectos aberto e contingente (RICOEUR, 1997, p. 372). De fato, não negamos aqui que o nosso amanhã seja marcado pela incerteza de seus acontecimentos e pela explosão de suas possibilidades. É isso, inclusive, que levou um autor como De Giorgi (2006, p. 234) a afirmar que nunca uma sociedade conviveu com tantas alternativas como a nossa, no sentido de que a abertura para o futuro expande nosso potencial para decisões, duplica a possibilidade de escolha e bifurca nossos caminhos para o agir possível. O problema é que, compreendido como inexoravelmente incerto, esse futuro revelar-se-ia inteiramente lançado ao acaso; como se não exigisse ser construído a partir do presente. Nosso amanhã seria de tal maneiro novo, que nossa bagagem não teria mais nenhuma utilidade e que até nossos projetos e promessas perderiam qualquer pertinência (OST, 2005b, p. 306). Dito de outro modo, o futuro quando concebido em sua total abertura, recai instantaneamente no vazio: sem que possamos projetar nossos passos vindouros, estamos condenados a vivenciar o presente como um instantâneo insignificante. 
Num sentido diametralmente oposto, é possível recorrer às reflexões de Ricoeur (1989; 1994a; 1997) acerca da noção de "horizonte de expectativa", de modo a atribuir ao futuro uma consistência humana a partir da capacidade do homem de pensá-lo e construí-lo prospectivamente. A expectativa, nesse sentido, pressupõe um futuro já presente, um projeto que se lança, desde aqui e agora, para um horizonte vindouro de esperança apto a mobilizar as ações do presente e dar nova luz às questões do passado. Com o homem, surge a possibilidade de uma construção antecipada do amanhã, uma vontade de orientá-lo e de torná-lo mais "tangível": "não fazer com que ele chegue, mas imprimir um sentido - significação e direção - ao que há de vir" (OST, 2005b, p. 28). É precisamente a partir desse "horizonte de expectativa" que uma comunidade histórica procura tornar seu futuro menos aleatório e caótico, atribuindo a suas próprias normas constitucionais a força para perpetuar no tempo e a energia para fomentar aprendizados futuros.

No que concerne à possibilidade de estabelecer vínculos com o futuro, a Constituição lança-se num "horizonte de expectativa" que deve constituir "o modelo de todo começo, senão do tempo, pelo menos no tempo, ou seja, de todo acontecimento capaz de inaugurar um curso novo de acontecimentos" (RICOEUR, 1997, p. 397). Normativamente, ela estabelece um compromisso e coloca a comunidade política na "obrigação de fazer" sobre o fundo de um espaço público regido por um pacto social em virtude do qual é preciso cumprir as próprias promessas. A partir de um ato de fundação, o povo constitui-se como um novo corpo políticojurídico, instituído de forma plural por cidadãos que, no exercício de sua autonomia política, assumem o compromisso, a mútua promessa, de reciprocamente reconhecerem-se iguais direitos de liberdade (CATTONI DE OLIVEIRA, 2009, p.389). Promessa mútua essa que deve criar laços com o futuro no sentido de lançar toda uma comunidade política na exigência de fazer surgir, a cada amanhã, uma sociedade melhor que a de hoje num compromisso jurídico sempre atual para com as suas vítimas. Desse modo, ainda que o horizonte vindouro seja incerto e a nossa vivência na temporalidade seja marcada radicalmente pela contingência, estamos aptos a projetar coletivamente a história que queremos contar e, portanto, podemos forjar nossa imagem do porvir político ao investirmos na duração dos direitos fundamentais que uma Constituição procura preservar. 
Com isso, uma Constituição passa a ter o papel de atribuir dimensão temporal aos nossos compromissos políticos: ela é um documento escrito e durável capaz de transformar a promessa de "viver junto" do ato fundador num processo constituinte que tem continuidade por meio de sucessivas gerações. Ela não representa, pois, um sonho que de tão distante é incapaz de orientar nossas ações para o futuro, mas um conjunto de normas e de compromissos sociais que engendra um horizonte político de expectativas que é sempre retomado no presente e se encontra continuamente em vias de ser realizado ${ }^{13}$. Pela promessa mantida, o presente tem a força de perseverar, em suma, de durar (RICOEUR, 1997, p. 396), o que implica que o futuro a que o projeto constitucional se reporta é sempre passível de ser exigido e construído no agora como parte de uma narrativa que se prolonga no tempo da comunidade política. Assim, o tempo da Constituição não é o da produção normativa instantânea e acelerada, mas o da forma jurídica estável e durável, que, por não perder inteiramente a sua identidade depois da mudança ocorrida neste ou naquele dos seus elementos, apropria-se de uma força ativa, ao mesmo tempo, motivadora e ordenadora da vida do Estado (HESSE, 1991, p. 11). Constituindo-se como a própria condição de possibilidade de uma vida política orientada em termos de Constituição, a durabilidade das normas assegura a persistência de uma comunidade conduzida por suas próprias promessas e torna plausível uma transformação social guiada pela projeção de tais compromissos.

Tendo em vista que a Constituição é o instrumento jurídico, por excelência, de ligação com o futuro, será possível dizer que o seu núcleo essencial estaria destinado à perenidade? $\mathrm{Ou}$ em outros termos, é legítimo ainda recorrermos à figura das “cláusulas pétreas" em tempos radicalmente contingentes como modo de assegurar os meios para a auto-identificação do corpo político criando fortes vínculos com o amanhã jurídico? Não caberia, ao contrário, cada geração assumir o seu destino e reescrever o direito, à sua vontade?

De forma a orientar-nos na tentativa de responder essas questões que estão diretamente ligadas à noção desse futuro, projetado e antecipado, que, perpassado pelo sentido dado pelo

\footnotetext{
${ }^{13}$ O horizonte é um conceito em Ricoeur (1989) que traz intrínseca a ideia de que o projeto visado nunca poderá ser alcançado totalmente. Mas tal noção de horizonte pode se diferenciar bem da idéia de uma utopia "inalcançável e paralisante" na medida em que, apesar de sempre estar a um passo à frente, é requerido no hoje como mudança da realidade e está sempre em movimento de transformação, devido ao seu caráter de inacabado. Para complementar a tese defendida aqui, poderíamos muito bem recorrer à ideia de "porvir" de Derrida. O "porvir" é o futuro cobrado no presente; é algo que está sempre por se realizar, embora nunca se realize por completo. Ver Derrida (2007) e Costa Junior; Galuppo (2009).
} 
homem, é capaz de fazer o próprio tempo durar, recorremos aqui às reflexões de Jon Elster (1993, p. 93 e ss.) acerca do problema. Apropriando-se de uma passagem da obra "Odisséia", Elster (1993) procura elaborar uma metáfora para fundamentar sua tese a respeito da legitimidade dos limites do poder de reforma de uma Constituição na perspectiva do constitucionalismo democrático. A metáfora criada por Elster apoia-se na estratégia que Ulisses concebeu para conseguir prosseguir a sua rota passando pela ilha das Sereias sem que ele e sua tripulação fossem arruinados pelo seu encantamento. Homero narra que Ulisses tinha plena consciência de que, ao percorrer seu destino, seria atraído pelo canto demasiado irresistível das sereias, o que conduziria sua embarcação ao naufrágio. Em razão disso, ele toma as medidas necessárias para resistir a este canto: determina aos seus marinheiros que tapem seus ouvidos com cera e que o amarrem no mastro do seu próprio navio, não o soltando em hipótese alguma ainda que ele o ordenasse. Tomadas as devidas providências, Ulisses consegue passar ao largo dos rochedos, ouvir o canto das sereias, sem, no entanto, a ele sucumbir.

Nesse mesmo sentido, o pré-comprometimento de Ulisses, que limitou o poder de sua vontade no futuro para evitar a morte, poderia ser comparado àquele a que se submete o povo, quando atribui a si normas constitucionais fundamentais, e limita seu poder de reforma vindouro, para evitar que, vítima de suas próprias paixões e fraquezas momentâneas, possa pôr em risco a sua própria existência enquanto corpo político (ELSTER, 1993). Ao estabelecer que certos direitos e procedimentos encontram-se acima dos órgãos ordinários de decisão política ou mesmo fora do seu alcance por força das limitações materiais ao poder constituinte derivado, as Constituições também funcionariam como proteção contra aquelas inconsistências temporais, protegendo as metas de longo prazo que são constantemente minadas por maiorias ávidas por maximizar os seus interesses imediatos (VIEIRA, 1997, p.54).

Assim, a analogia à trama de Ulisses procura abrir caminho para uma reflexão do próprio fundamento da existência de normas intangíveis no sentido de colocar as Constituições ao abrigo das maiorias eventuais e dos movimentos passionais populares para salvaguardar princípios fundamentais, nos quais repousa o edifício da vida política (OST, 2005b, p. 252). Ainda que tal analogia não abarque, logicamente, toda a complexidade do 
problema das limitações ao poder de reforma ${ }^{14}$, como admite o próprio Elster (2002, p.115), a imagem de Ulisses, com as mãos atadas ao mastro da embarcação, por vontade própria, é paradigmática dos sistemas constitucionais democráticos, em que a comunidade política, através de um procedimento constitucional rígido, restringe seu próprio poder de decisão, objetivando perpetuar sua liberdade de decidir (VIEIRA, 1997, p.55). Nas duas situações, a possibilidade de ação por parte do indivíduo ou do corpo político é bloqueada com o objetivo de autopreservação (VIEIRA, 1997, p.55). Desse modo, a limitação imposta tanto a Ulisses quanto ao poder constituinte atual talvez nem possa ser concebida como uma forma de debilitação do agir vindouro, na medida em que constitui condição sem a qual a própria existência futura de ambos naufragaria.

É nesse sentido que as Constituições podem ser autorrestritivas de uma maneira que engendre possibilidades. Isso significa dizer que elas não somente limitam o poder, também podem criar e organizar o poder, assim como dar ao poder certa direção. (HOLMES, 1999, p. 19). Nesse paradoxo político ${ }^{15}$, as limitações ao poder de reforma restringem a comunidade histórica, impedindo-a que reescreva suas normas fundamentais à sua própria vontade, ao mesmo tempo em que a habilitam a agir politicamente segundo suas próprias promessas, funcionando como garantia contra o enfraquecimento de um núcleo jurídico-político essencial para a autodeterminação dos cidadãos na construção continuada de sua vida política. Além da proteção da estrutura central do poder contra uma total ruptura, tais limitações buscam impedir que mudanças constitucionais "normais" gerem uma erosão dos princípios e compromissos básicos capazes de fomentar o próprio exercício da ação política ${ }^{16}$. Do contrário, sem nunca podermos subtrair das "maiorias" a possibilidade de decidir determinadas matérias tidas como fundamentais, estaríamos fadados a pensar o ato criador

\footnotetext{
114 "No caso de Ulisses ocorre uma limitação individual, enquanto no processo constitucional a rigidez imposta pelas decisões constituintes, além de ter um caráter supra-individual, pois é imposta ao conjunto da sociedade, é também uma limitação às gerações futuras, e não apenas àquela que estabeleceu a Constituição" (VIEIRA, 1997, p.54).

115 “As mais admiráveis análises do governo constitucional pressupõem esse paradoxo de uma racionalidade que é também poder, e poder suscetível de voltar a ser insensato: é chocante, com efeito, que a lei fundamental que torna esse governo viável proceda instituindo oposições, limitações, compensações entre Estado, as instituições e os cidadãos" (RICOEUR, 1995b, p. 50).

116 “Sem dúvida, uma modificação radical da ordem constitucional continua sempre possível (fala-se então de abolição da Constituição), mas um ato desse tipo deriva de uma ruptura que exige lucidez para qualificá-la 'revolucionária' e não de uma transformação conforme o direito positivo" (OST, 2005b, p. 258).
} 
jurídico como uma determinação sem entraves, na qual o poder político passa a ser concebido como manifestações pontuais e imediatas de uma vontade ilimitada que se coloca, inclusive, acima de qualquer direito.

O resultado disso é aquilo que, na trilha indicada por Ricoeur, temos condenado em toda nossa reflexão, a saber, a cisão do presente político em relação às narrativas e às expectativas, o que se reflete, para nós, na incapacidade de atribuirmos sentido aos nossos compromissos vindouros e de assumir seus símbolos como parte daquilo que queremos construir em via constitucional. Ora, o futuro projetado, ao contrário de ser um modo de dominar prospectivamente nosso amanhã político, suprimindo sua contingência, é aquilo que possibilita que um povo imagine um futuro possível para si, baseado no próprio desdobramento de sua história. Ele cria, pois, uma imagem de si, a ser perseguida no tempo, comprometendo-se a salvaguardar direitos e princípios fundamentais contra as tiranias majoritárias e os impulsos políticos imediatistas, numa situação na qual respeitar essa "imagem" significa menos alinhar-se de "modo conservador" numa vontade antiga e ultrapassada do que dar efeito a um projeto político sempre por vir que ainda não deu todos os seus frutos. "Paradoxalmente, a fidelidade a esta promessa analisar-se-ia nestas condições, menos como respeito em relação às gerações passadas, quanto como consideração em relação às gerações futuras" (OST, 2005b, p. 265).

O que acontece é que limitar o poder de mudança dos nossos comprometimentos essenciais para auto-identificação do corpo político - é procurar "ver mais longe". Na medida em que somos constantemente atacados pelas urgências do agora ou pela pressa na satisfação de nossas necessidades políticas momentâneas, tendemos a ter mais dificuldade de enxergar "além", o que torna, por sua vez, quase insuportável uma ação concreta que lide com os primeiros passos para a realização de nossos projetos de médio e longo prazo. É nesse percurso que Hume chega a afirmar que "muito mais frequente é os homens serem distraídos de seus principais interesses, mais importantes, mas mais longínquos, pela sedução de tentações presentes, embora muitas vezes totalmente insignificantes” (HUME, 1973, p. 225). Isso nos remete à "síndrome da pressa" que Marramao enfatiza: essa velocidade das mudanças (normativas) que perde de vista o próprio objeto que se pretendia perseguir (MARRAMAO, 2008). As cláusulas pétreas justificar-se-iam, pois, nessa capacidade de 
possibilitar a longa duração dos compromissos fundamentais, obrigando-nos a manter os olhos fixos num projeto de futuro que apesar de mais árduo de ser realizado por completo, deve ser empreendido desde já. Assim, as restrições constitucionais, como bem assevera Elster, prestar-se-iam a proteger as sociedades democráticas de suas próprias miopias crônicas (ELSTER, 2002, p. 11).

Contudo, é necessário cautela ao se pronunciar acerca do núcleo imodificável de uma Constituição. De fato, o que possibilita que uma norma integre a esse núcleo é, além de sua imprescindibilidade para a autoidentificação do corpo político e para a autodeterminação dos cidadãos, o caráter propriamente aberto e, por vezes, indeterminado de seu conteúdo. Essa indeterminação última quanto aos fundamentos da lei (RICOEUR, 1991a, p. 305) tem o sentido de abrir um espaço de contingência irredutível como forma de permitir que o conteúdo dos direitos fundamentais seja reiteradamente objeto de discussão e reelaboração no futuro ${ }^{17}$. "A esse respeito é inútil - quando não perigoso - prever um consenso que ponha fim aos conflitos. A democracia não é um regime sem conflitos, mas um regime no qual os conflitos estão abertos e negociáveis segundo as regras de arbitragem conhecidas." (RICOEUR, 1991a, p.302). Nesse sentido, a promessa constitucional, apesar de lançar-se a um horizonte vindouro, não pretende vinculá-lo completamente de antemão, na medida em que define os direitos fundamentais como um núcleo imodificável mínimo capaz de possibilitar uma arena em que as lutas das correntes políticas minoritárias para reorientar conteúdos normativos são travadas a partir dos procedimentos jurídico-democráticos. ${ }^{18}$ Compreendidos desta forma, os direitos fundamentais, embora não sujeitos a supressão pela via da reforma constitucional, podem - ou melhor, devem - ter o seu sentido aprofundado a

\footnotetext{
${ }^{17}$ É a partir daqui que ganha força a importância da interpretação do direito, o que abriria, aliás, a possibilidade de mutação constitucional. Essa última, poderíamos dizer, refere-se a modos complexos de mudança na Constituição sem supressão do seu texto. Justamente por possuir um alto grau de abstração, os direitos fundamentais contidos na Carta Constitucional permitem o surgimento de espaços intertextuais que abrem espaço, inclusive, para atribuição de sentidos inovadores num mesmo texto de lei. A mutação constitucional revela-se, desse modo, como apropriada para expressar a própria continuidade da reescrita da Constituição em conformidade com as novas experiências adquiridas no tempo. Todavia, não pretendemos nesse trabalho discutir o alcance desse recurso ou até que ponto tais mutações implicariam uma monopolização do sentido da Constituição por parte de uma instância jurídica superior, como o Supremo Tribunal Federal. Tal empreendimento desviarnos-ia profundamente do objeto de nossa pesquisa.

${ }^{18} \mathrm{O}$ espaço deixado em aberto é, nas Constituições, ocupado pelos direitos fundamentais, uma vez que são "dotados de complexidade suficiente para levarem uma vida jurídica própria" (LUHMANN, 1996, p.28), ou em outros termos, foram formulados de modo que seu significado pudesse adquirir conotações diferentes na história política de um povo.
} 


\section{2}

cada geração a partir do recurso reiterado à interpretação da Constituição. É desse modo que aproximamos a construção jurídica do ideal narrativo, sem o qual uma comunidade histórica jamais seria capaz de articular tradição e inovação, memória e promessa na dinâmica de uma Constituição no tempo:

Como na imagem de Ulisses, os pré-comprometimentos constitucionais, assumidos a partir da adoção de cláusulas pétreas, só serão legítimos se formulados de maneira a habilitar a continuação da jornada da sociedade, por intermédio dos caminhos traçados pelos seus próprios cidadãos (VIEIRA, 1997, p. 83).

O futuro projetado abre, assim, a possibilidade de se construir um tempo constitucional próprio que se lança, duradouramente, numa fidelidade aos princípios norteadores da ação política, permitindo, contudo, que eles sejam aprofundados a partir de lutas pela ampliação de seu sentido: eis aí a possibilidade de uma coerência poética no direito. Tudo se passa como se o futuro de uma Constituição só fosse aberto a partir do respeito a um projeto político de longo prazo e só fosse prometido a partir das ressignificações de seu texto a serem atribuídas pelos grupos minoritários, no sentido de transformar sua realidade. Daí, diríamos que a escrita continuada da narrativa constitucional desenvolve-se como uma "concordância-discordante", uma temporalidade simultaneamente aberta e dominada o que implica que "toda a concepção de justiça requer uma coerência que não é somente de preservar, mas de construir" (RICOEUR, 1991a, p. 324).

\subsection{Um presente responsável}

Como herdeiro de boa parte das reflexões de Agostinho, Ricoeur (1994b) pensa o tempo em toda a sua radicalidade, como se a vivência temporal fosse marcada por uma contingência insuprimível, na qual o passado já foi, o futuro ainda não é e o presente perece a cada instante. Essa dificuldade de inscrevermos numa temporalidade verdadeiramente duradoura traz-nos a sensação de que nossa existência é marcada pela finitude e pelo perecimento de uma maneira inexorável. Perpassados por essa temporalidade fugaz, os homens e suas comunidades parecem lançados numa ausência completa de sentido seja em relação à sua vida pessoal seja em relação à sua experiência política. De certo modo, a crise 
de nossos tempos que tanto insistimos reflete a radicalização ainda mais latente dessa perspectiva de um fluxo incessante do tempo, numa situação na qual a vivência do presente é meramente a vivência de um agora perecível e desconectado tanto do passado quanto do futuro.

No entanto, sem se ater a esse diagnóstico pessimista, Ricoeur (1994b) crê que o homem é o único ser verdadeiramente capaz de dar sentido à heterogeneidade e multiplicidade de suas experiências no tempo, construindo uma temporalidade duradoura e demasiadamente humana a partir de suas próprias narrativas e promessas. O homem rememora suas experiências passadas e projeta suas aspirações no futuro dando "à consciência histórica seu valor qualitativo, irredutível à dimensão simplesmente cronológica do tempo" (RICOEUR, 1994a, p. 88). Por isso, ele tem o poder de trapacear o tempo a partir de sua capacidade de arrancar-se do seu escoamento irreversível, ligando o que, a cada instante, ameaça desligar-se (OST, 2005b, p. 28). Com ele, surge, de fato, a possibilidade de uma retomada reflexiva do passado e de uma construção antecipativa do futuro; como se estivéssemos sempre aptos a reinterpretar o que já foi, tirando partido de seus ensinamentos e a orientar o que ainda não é, imprimindo uma direção ao que há de vir (OST, 2005b, p. 28).

Esta fecundação recíproca entre passado e futuro, é preciso salientar agora, se desenvolve num "presente vivo" (RICOEUR, 1994a; 1997) que garante ao tempo uma consistência humana capaz de dar sentido - entendido a uma só vez como direção e significação - aos nossos comprometimentos passados e nossas esperanças de um porvir político. O presente vivo não é, pois, redutível a um ponto na linha do tempo, um simples corte entre um antes e um depois, mas o mediador da dialética entre espaço de experiência e horizonte de expectativa: ele é rico de passado recente e de futuro iminente (RICOEUR, 1994a, p. 88). Ao contrário de se constituir como instantes desconexos em que o passado parece cada vez mais longe e o futuro cada vez mais fortuito, o presente é o momento em que é possível imaginar o próprio tempo na sua "justa" medida e, com isso, colaborar para a construção poética da vida política na temporalidade, abrindo, assim, um espaço para a esperança: 
134

\begin{abstract}
possibilidade de uma construção neguentrópica [quer dizer humana] do tempo social. Não que queiramos negar o caráter irreversível do tempo: o passado está terminado e o futuro indeterminado. Logo, não se trata nem de "voltar atrás", nem de "parar o curso do tempo", trata-se antes, de regenerar o tempo que passa, conferindo-lhe a espessura de uma duração real, graças à fecundação recíproca de um passado que, se bem que terminado, não esgotou suas promessas, e de futuro que se bem que indeterminado, não é totalmente aleatório. É que se, como escreveria Marx, 'a história não repete os pratos', seu sentido, entretanto, jamais está definitivamente estabelecido: 'cada sociedade reescreve sua história à medida em que ela mesma muda", notava R. Aron, que acrescentava: 'o passado só é definitivamente fixado quando não tem mais futuro'. E poderíamos dizer, em contrapartida, que uma sociedade amputada de suas raízes, órfã de sua história, encontra barrado seu acesso ao futuro (OST, 2005b, p. 29).
\end{abstract}

É desse poder, fortemente humano de reinventar as imbricações com o seu próprio tempo, que a escrita da narrativa constitucional também se desenvolve em ritmos próprios, reorganizando as experiências jurídicas do passado e projetando expectativas a serem perseguidas em direção ao futuro. Ao deslocar-se no sentido do passado, o presente jurídico, diríamos, redescobre o sentido do processo constituinte de elaboração de uma Constituição e retira dele a possibilidade de realização, aqui e agora, das potencialidades abafadas e das promessas não cumpridas do nosso direito. Assim, somos capazes de narrar o passado, tirar partido de seus ensinamentos e liberar sua carga de futuro, apropriando-nos do texto constitucional para ressignificá-lo à luz das lutas, reivindicações e interpretações normativas presentes. Em direção ao futuro, esse mesmo presente tem a força de durar, de orientar nossos passos vindouros a partir do valor atribuído à promessa constitucional e sua capacidade de permitir que os compromissos e direitos fundamentais se perpetuem ao longo da história social ao mesmo tempo em que seu sentido torna-se continuamente passível de reelaboração e de aprofundamento pelas gerações posteriores.

É desse modo que diríamos que o tempo da Constituição é, simultaneamente, mais cadenciado que o tempo acelerado das mudanças normativas desenfreadas e mais veloz que o tempo congelado das interpretações conservadoras e hegemônicas do texto de nossa Lei Fundamental. Esse tempo busca, pois, a conciliação entre estabilidade e inovação, uma vez que exige tanto a durabilidade das normas mais fundamentais do corpo político mediante o respeito a uma promessa que engaja a ação política no futuro; quanto à maleabilidade do 
significado do texto normativo da Constituição sempre aberto à refiguração do seu conteúdo com base nas narrativas, até então, silenciadas e não reconhecidas na esfera pública ${ }^{19}$.

Assim, uma nova coerência no direito é tecida quando estamos aptos a permitir que a produção normativa seja, a cada dia, afetada pelo passado, a saber, pela pluralidade de seus signos, narrativas e significados que foram deixados para trás e, por isso, necessitam ser incorporados pelas nossas esperanças de agora de modo que possamos abrir a nossa realidade política ao futuro: é preciso, então, fazer justiça ao passado dos grupos reprimidos, das coletividades abafadas que ainda não tiveram seu devido lugar na escrita da narrativa constitucional, permitindo que um outro amanhã possa ser, desde já, construído. No presente, liberar as cargas de um passado aberto e comprometer-se com um futuro duradouro, eis o justo compasso do tempo da Constituição.

Ora, esse jogo complexo entre passado e futuro só pode ser operado porque o presente não se reduz à simples presença do meio, isto é, à percepção do mundo tal qual ele se oferece ao nosso olhar (RICOEUR, 1994a, p. 88). O momento presente já não é, então, uma categoria do ver, mas sim do agir e do padecer, o que significa que ele comporta a forma ativa e prática daquilo que podemos chamar iniciativa se entendemos com isso a capacidade de intervir no curso das coisas, o poder de produzir novos acontecimentos. É nesse sentido que o verbo "começar" exprime, muito bem, a significação desse tempo: "começar é dar às coisas um curso novo, a partir de uma iniciativa que anuncia uma sequência e, assim, abre uma duração. Começar é começar a continuar: uma obra deve ser seguida" (RICOEUR, 1997, p. 392).

Compreendido como um "ato de iniciar", o presente torna-se, por excelência, o tempo de "julgamento e decisão" que assegura aos homens a possibilidade de se inserir num projeto sensato de ação pessoal e coletiva, fazendo com que a realidade não seja totalizável. Com isso, intervir no mundo é poder reinventar, hoje, as promessas do passado de modo que se tornem mobilizadoras das nossas esperanças de futuro. O presente é, assim, compreendido como o momento da ação político-constitucional, aqui e agora, que se apropria da própria história dos direitos, arranca-lhe as promessas não-realizadas, dá novo rumo às interpretações normativas e ainda, se necessário, submete o próprio texto da Constituição a eventuais

\footnotetext{
${ }^{19}$ Sobre a questão da refiguração dos direitos fundamentais e do sentido de uma Constituição a partir dos grupos oprimidos, ver Galuppo (2009).
} 


\section{6}

reformas - embora não atinja o seu núcleo fundamental imodificável. Essa perspectiva que faz da nossa narrativa constitucional uma história carregada por tradições ainda vivas encontra consonância com a própria concepção de democracia desenvolvida por Ricoeur: "a democracia", diz o autor, "contrariamente aos regimes que retiravam a sua autoridade de entidades anteriores ou superiores, está continuamente em vias de se fundar" ${ }^{20}$ (RICOEUR, 1991b, p.255, tradução nossa).

Ora, não é somente do passado ou mesmo do futuro que a democracia, assim como a própria ação político-constitucional, encontra sua legitimidade, mas é a partir desse presente vivo e histórico cuja visão do futuro tem a força de reativar as potencialidades não realizadas do passado, dando novo rumo à realidade. A tarefa é, então, de re-fundar a própria promessa de um viver junto consolidado em normas, relembrando os nossos próprios percursos de reconhecimento de direitos e reavivando, aqui e agora, o sentido de nossa Constituição para a consolidação de uma "democracia [...] sempre em curso e em crise" ${ }^{21}$ (RICOEUR, 1991b, p.255, tradução nossa). O que esta abertura recoloca é a constitucionalização como tarefa permanente, e transmitida pelo passado, a cada nova geração - e, assim, os grandes eventos que marcam a sua descontinuidade e abertura poderão ser retrospectivamente recompostos como partes desse aprendizado histórico, que representa a experiência da cidadania -, no exercício da autodeterminação jurídico-política e na defesa de uma identidade constitucional aberta, sobre o pano de fundo de uma história mundial do constitucionalismo democrático (CATTONI DE OLIVEIRA, 2009, p. 392). E talvez esta seja justamente a nossa herança mais importante a ser resgatada do passado, "a responsabilidade no presente por um futuro-emaberto" (CATTONI DE OLIVEIRA, 2009, p. 392, grifo nosso).

Desse ponto de vista, a idéia de responsabilidade extrai uma das significações centrais para a construção da narrativa constitucional: o compromisso com o próprio tempo de uma comunidade histórica nas suas dimensões passada, presente e futura. Do ângulo do futuro, a responsabilidade implica que os cidadãos e os seus representantes políticos assumam a consequência dos seus atos, isto é, admitam alguns acontecimentos vindouros como

\footnotetext{
220 "La démocratie, à la différence des régimes qui tiraient leur autorité d'entités préalables ou supérieures, est sans cesse en train de se fonder" (RICOEUR, 1991b, p.255).

221 "Démocratie [...] toujours en cours et en crise" (RICOEUR, 1991b, p.255).
} 
representantes deles próprios, a despeito do fato de que não foram expressamente previstos e desejados; esses acontecimentos são, apesar deles, sua obra (RICOEUR, 1991a, p.343). Do lado do tempo pretérito, "a responsabilidade implica que assumamos um passado que nos afeta sem que ele seja inteiramente nossa obra, mas que nós assumimos como nossa" (RICOEUR, 1991a, p.344). É o caso de um sentimento de endividamento mútuo que nos provoca na escrita da história constitucional de hoje a responder pelo outro, nos tornando responsáveis pela sua condição.

Essas duas acepções, prospectiva e retrospectiva, da responsabilidade juntam-se ainda para a responsabilidade do presente: “conservar responsável agora é, de uma maneira que falta precisar, aceitar ser considerado hoje o mesmo que aquele que fez ontem e que fará amanhã” (RICOEUR, 1991a, p.344). É justamente nesse sentido que a conservação de uma identidade constitucional no tempo possibilita que sejamos responsáveis, enquanto parte desse projeto que se estende na história de uma comunidade política, pela concretização de nossos compromissos mais fundamentais. "Tudo se passa como se nossos atos se inscrevessem num grande livro de contas, para serem aí registrados e arquivados" (RICOEUR, 1991a, p. 345). Talvez essa metáfora de Ricoeur possa nos levar a pensar sobre a importância do aspecto narrativo da constitucionalização, visto que a imagem de um encadeamento das interpretações e das normas jurídicas produzidas ao longo do tempo de uma comunidade política implica a "recapitulação no presente da responsabilidade das consequências e da do endividamento" (RICOEUR, 1991a, p. 345). Assim, somos mais uma vez conduzidos a esse jogo complexo entre experiência e expectativa que faz com que a escrita de nossa Constituição, aqui e agora, não se torne um exercício jurídico aleatório e desprovido de sentido político no tempo.

É a partir da ideia de que podemos dar sentido às nossas experiências normativas no tempo e nos responsabilizar pelos nossos comprometimentos em direção ao futuro que poderíamos dizer que "não temos a necessidade de saber para aonde vai a história para compreender nosso dever a seu respeito" (RICOEUR, 1994a, p. 94). Dessa forma, a esperança e a confiança que Ricoeur deposita na história não dependem do seu sentido imanente ou de uma providência ou mesmo de um progresso sem limites, mas do engajamento e da responsabilidade dos cidadãos face aos desafios políticos. No presente, somos interpelados pela responsabilidade de continuar a escrever uma narrativa constitucional que resgata, 
138

retrospectivamente, seus próprios percursos e que se responsabiliza pela reabertura constante da Constituição a todos os pontos de vista que a prática política e jurídica cotidiana deixa nos seus limites ou mesmo exclui. Essa responsabilidade abre, assim, o caminho para uma coerência poética no direito que dá sentido à nossa vida política e permite que pensemos a "justa medida" do tempo da Constituição, que não é nem tradição rígida e nem inovação insensata. Esta poética da Constituição se perfaz a partir de nossa responsabilidade inafastável pelo outro, pelo tempo e pela nossa própria história, embora seja, de fato, uma esperança sem qualquer garantia de sucesso:

Continuo a deixar lugar para a esperança. Uma esperança construída sobre o quê? [...] minha esperança está na linguagem, a esperança de que haverá sempre poetas, de que haverá sempre pessoas para refletir sobre eles e pessoas para querer politicamente que essa palavra, que essa filosofia da poesia, produza uma política (RICOEUR, 2002, p. 66).

\section{Considerações Finais}

Pensar a trama que interconecta as relações entre narrativa, tempo e Constituição significa adentrar num terreno teórico instigante que pode suscitar importantes reflexões para questões práticas. Uma dessas, pretendida aqui, foi a de analisar a dinâmica de uma Constituição no tempo e, com isso, a necessidade de se pensar a mudança normativa, inserida numa intriga jurídico-narrativa que articula passado, presente e futuro.

Em direção ao passado, a escrita constitucional retoma as narrativas e os percursos de lutas por direitos inscritos na Constituição para lançar-lhes uma nova luz no presente. Sem precisar alterar a Constituição o tempo todo, essa perspectiva autoriza que interpretemos às nossas próprias normas de um modo diferente, fazendo valer aqui e agora as promessas e direitos ainda não cumpridos do nosso passado.

Já, no sentido do futuro, a Constituição esforça-se para durar, para projetar um amanhã apesar da sua imprevisibilidade. Nesse caminho, algumas normas podem ser tidas inclusive como imodificáveis por representar um núcleo imprescindível para a autoidentificação do corpo político e para a autodeterminação dos cidadãos. 
E, finalmente, na construção do presente, a ação jurídico-constitucional articula passado e futuro para conferir aos nossos compromissos, hoje, a força de intervir e mudar a realidade política de modo sempre responsável pelas dívidas do ontem e pelas consequências do amanhã. Uma responsabilidade sempre atual capaz de inscrever a escrita constitucional numa temporalidade que põe em xeque a aceleração desenfreada dos ritmos das mudanças, tão comum nos dias de hoje. Essa temporalidade permite inserir as transformações na história, a partir da reorganização das nossas experiências jurídicas numa duração significante de modo a conferir orientação e sentido às mudanças mais importantes do nosso texto constitucional.

\section{REFERÊNCIAS}

ABEL, Olivier. Paul Ricoeur: a promessa e a regra. Trad. Port. Joana Chaves, Instituto Piaget, 1997.

ARENDT, Hannah. Da Revolução. Trad. Fernando Dídimo Vieira. São Paulo: Ática, 1990.

BONAVIDES, Paulo. Curso de direito constitucional. 7.ed. São Paulo: Malheiros, 1998.

CATTONI DE OLIVEIRA, Marcelo Andrade. Democracia sem espera e processo de constitucionalização: uma crítica aos discursos oficiais sobre a chamada "transição política brasileira". In: CATTONI DE OLIVEIRA, Marcelo Andrade; MACHADO, Felipe Daniel Amorim (org). Constituição e Processo: a resposta do constitucionalismo à banalização do terror. Belo Horizonte: Del Rey, 2009.

CHAUÍ, Marilena. Simulacro e poder: uma análise da mídia. São Paulo: Editora Fundação Perseu Abramo, 2006

COSTA JUNIOR, Ernane Salles. A Força Normativa da Memória Constitucional: uma análise da trivialização das reformas na Constituição de 1988 a partir da obra Revolução dos Bichos de George Orwell. In: Anais do XVIII Encontro Nacional do CONPEDI, 2009. Florianópolis : Fundação Boiteux, 2009.

COSTA JUNIOR, Ernane Salles; GALUPPO, Marcelo Campos. A democracia como promessa: entre a imprescindibilidade do cálculo e a experiência aporética da justiça. In: CATTONI DE OLIVEIRA, Marcelo Andrade; MACHADO, Felipe Daniel Amorim (org). Constituição e Processo: a resposta do constitucionalismo à banalização do terror. Belo Horizonte: Del Rey, 2009. 
DE GIORGI, Raffaele. Direito, tempo e memória. São Paulo: Quartier Latin, 2006.

DERRIDA, Jacques. Força de lei: o fundamento místico da autoridade. São Paulo: Martin Fontes, 2007.

ELSTER, Jon. Ulises desatado: estudios sobre a racionalidad, precompromisso y restricciones. Tradução: Jordi Mundo. Barcelona: Gedisa, 2002.

ELSTER, Jon. Ulises and the Sirens: studies in rationality and irrationality. Cambridge: Cambridge University Press, 1993.

GALUPPO, Marcelo Campos . A hora de brilhar: direitos fundamentais na trilha da Literatura. In: GALUPPO, Marcelo Campos. (Org.). Constituição e democracia: Fundamentos. 01 ed. Belo Horizonte: Fórum, 2009, v. 01, p. 263-276.

GARCÍA-VILLEGAS, Mauricio. Law as hope. Constitutions, Courts and Social Change in Latin America 1. Coimbra: Colóquio Internacional Direito e Justiça no Século XXI, 2003.

HARVEY, David. A condição pós-moderna. 12 ed. São Paulo: Loyola, 2003.

HESSE, Konrad. A força normativa da Constituição. Porto Alegre: S. A. Fabris, 1991.

HOLMES, Stephen. El precompromiso y la paradoja de la democracia. In: Constitucionalismo y Democracia. 1999. Disponível em: $<$ http://cablemodem.fibertel.com.ar/seminario/up/holmes.pdf $>$ Acesso em: 9 de ag. 2010.

HONNETH, Axel. Observações sobre a reificação. Civitas. V.8, n.1, p. 68-79, jan.-abr. 2008.

HUME, David. Da origem do governo. In: Ensaios Morais, Políticos e Literários. Trad. Antonio Sérgio [et al.]. São Paulo: Abril Cultural, 1973.

KIRSTE, Stephan. Constituição como início do Direito Positivo: A estrutura temporal das constituições. In: Anuário dos cursos de pós-graduação em Direito, Recife, n. 13, UFPE, 2003.

KIRSTE, Stephan. O direito como memória cultural. Revista Mestrado em Direito, Osasco. Ano 8, n. 2, p. 125-143, jul./dez. 2008.

KOSELLECK, Reinhart. Aceleración, prognosis y secularización. Valência: Pré-Textos, 2003.

KOSELLECK, Reinhart. Futuro passado: contribuição à semântica dos tempos históricos. Rio de Janeiro: Ed. PUC-Rio, Contraponto, 2006. 
LUHMANN, Niklas. A Constituição como Aquisição Evolutiva. 39p. Tradução livre

feita por Menelick de Carvalho Netto para fins acadêmicos da obra: La costituzione come acquisizione evolutiva. In: ZAGREBELSKY, Gustavo (coord.). et alli. Il Futuro

Della Costituzione. Torino: Einaudi, 1996.

MARRAMAO, Giacomo. Kairós: apología del tiempo oportuno. Barcelona: Gedisa, 2008.

MARRAMAO, Giacomo. Poder e secularização: as categorias do tempo. São Paulo: UNESP, 1995.

MORETZSOHN, Sylvia. A velocidade como fetiche - o discurso jornalístico na era do "tempo real". 2000. Dissertação (Mestrado). Universidade Federal Fluminense, Rio de Janeiro.

OLIVA-AUGUSTO, Maria Helena. O moderno e o contemporâneo: reflexões sobre os conceitos de indivíduo, tempo e morte. Tempo Social; Rev. Sociol. USP, S. Paulo, 6(1-2): 91-105, 1994 (editado em jun. 1995)

OST, François. Contar a lei: as fontes do imaginário jurídico. São Leopoldo: UNISINOS, 2005a.

OST, François. Contar a lei: as fontes do imaginário jurídico. São Leopoldo: UNISINOS, 2005a.

OST, François. O tempo do direito. Bauru, SP: EDUSC, $2005 b$.

RICOEUR, Paul. A crise da consciência histórica e a Europa. Lua Nova : Revista de Cultura e Política, São Paulo, n.33, p.87-95, maio 1994a.

RICOEUR, Paul. A memória, a história, o esquecimento. Tradução: Alain François. Campinas, SP: Editora da UNICAMP, 2007.

RICOEUR, Paul. O si-mesmo como um outro. Campinas (SP): Papirus, 1991a.

RICOEUR, Paul. O perdão pode curar? 1996. Disponível em: $<$ http://www.lusosofia.net/textos/paul_ricoeur_o_perdao_pode_curar.pdf $>$ Acesso em: 2 de jun. 2009.

RICOEUR, Paul. Paul Ricoeur: o único e o singular. Tradução Maria Leonor F. R. Loureiro. São Paulo: Ed UNESP; Belém , PA: Ed. da universidade Estadual do Pará, 2002.

RICOEUR, Paul. Postface au temps de la responsabilité. In: LENOIR, Frédéric. Le Temps de la Responsabilité. Paris: Arthème Fayard, 1991b.

RICOEUR, Paul. Tempo e narrativa. Campinas (SP): Papirus, 1994b- v. 1 
142

RICOEUR, Paul. Tempo e narrativa. Campinas (SP): Papirus, 1997- v. 3

SARAPU, Daniel Vieira. Memento ou Amnésia do Direito. 2007. Disponível em: $<$ http://www.conpedi.org.br/manaus/arquivos/anais/bh/daniel_vieira_sarapu.pdf $>$ Acesso em: 10 de Abr. 2010.

SARAPU, Daniel Vieira. O papel da memória na narração do direito: contar o direito fundamental à não discriminação racial. 2008. Disponível em: $<$ http://conpedi.org/manaus/arquivos/anais/salvador/daniel_vieira_sarapu.pdf.> Acesso em: 11 de setembro de 2009.

SILVA. Paulo Thadeu Gomes da. Direito e Modernidade: lineamentos para uma teoria da reforma constitucional. Boletim Científico: Escola Superior do Ministério Público da União.. Brasília: ESMPU, v.4, n.17, p. 239-269, out./dez. 2005.

VERDÚ, Pablo Lucas. Curso de derecho político. Vol IV. Madrid: Tecnos, 1984.

VIEIRA, Oscar Vilhena. A constituição como reserva de justiça. Lua Nova, n. 42, p. 53-97, 1997.

Artigo recebido em 12 de março de 2012 e aceito em 07 de maio de 2012. 